\title{
Vocational Skills Development for Youths in the Informal Sector of the Economy in Africa
}

\author{
Kathure Catherine ${ }^{1}$, Mbijjiwe Jacob ${ }^{2}$ \\ 1 Instructor, Meru Technical Training Institute, P.O. Box111-60200 Meru, Kenya \\ 2 Ph.D Scholar, Osmania University, Hyderabad, 500007-India
}

\begin{abstract}
It is generally recognised that the development of relevant skills is an important instrument for improving productivity and working conditions, and the promotion of decent work in the informal economy, which represents the major employer in Africa. The increasing recognition that higher technical and vocational skills are crucial in enhancing competitiveness and contributing to social inclusion, decent employment, and poverty reduction has been a strong incentive for reform. African countries are therefore working towards improving the quality and skills levels of their labour forces. This is being facilitated through the Technical and Vocational Training Institutes. Education and skills can open doors to economically and socially rewarding jobs and can help the development of small informal-sector businesses, allow the re-insertion of displaced workers and support the transition from school to work for school drop-outs and graduates. Ultimately, developing job-related competencies among the poor, the youth and the vulnerable is recognised as crucial to progress in economic development and reducing poverty. The challenge is now to scale-up on the basis of successful pilot programmes. The number of enterprises capable of offering work-place training opportunities is limited, while many training institutions have poor delivery capacity and commonly lack funding. In turn, training programmes do not produce skilled graduates because training is of poor quality and the equipment obsolete. Many youths cannot access formal TVET, and few countries have training policies which emphasise skills development in the informal sector. Other obstacles include the low prestige of formal TVET in the eyes of the general public and parents who consider it to be an option suitable only for pupils who perform poorly in general education. This paper aims at providing a picture of technical and vocational skills development in African countries, exploring challenges and bottlenecks, highlighting good practices, and identifying priorities for further research. Specifically, the objectives will be to (a) update knowledge about the status of technical vocational education and training in the African region, $(b)$ explore issues and recent developments, and (c) distil a set of lessons and policy messages to guide skills development in the region. The focus of the analysis will be on the economics of skills development. Provision of financing of TVET will be examined through the lens of economic efficiency, balanced with attention to social equity.
\end{abstract}

Key words: Technical, Vocational Training, Youth, Employment, Poverty Reduction

\section{Introduction}

Human capital development is a process that improves an individual's knowledge and skills, and therefore his or her productivity in the home, community, or workplace. Skills, representing the acquisition and mastery of knowledge and processes used to earn a living, may be acquired in a formal technical or vocational school at tertiary levels; non-formally in a vocational training center (VTC) outside formal schooling; formally on the job through apprenticeship; or informally on the job through observation, unstructured learning activities, and practice.

African economies have experienced fundamental changes over the past decade. Many have undergone structural adjustment and policies have favoured increased market liberalization. Important initiatives have also taken place in vocational skills development in the face of growing deterioration in public financing of training systems. Cash-strapped systems have sought financing from new sources. Partnerships have developed through training authorities that have taken the management of skills development in some countries. Private training markets have appeared and grown. Training for the informal sector has come to the forefront in view of the growing scarcity of formal wage employment. In general, skills development is seen by many governments as an increasingly important factor in the multi-pronged drive to enhance productivity, stimulate economic competitiveness and raise people out of poverty. However, vocational skills development is also known to be costly and difficult for governments to get it right. It is a field in which it is crucial constantly to learn from experience, and to share knowledge. 


\section{Rationale for Training in Africa}

Empowering the youth through vocational training in Africa is highly based on facts by Manpower Group (2012) in their research on youth employment challenges and solutions that reveal a declining trend in labour force participation for the youth from 53.8\% in 1998 to $48.8 \%$ in 2011. This begs for answers to; why the youth are falling out of jobs and where do they go?

Improving the knowledge and skills of workers is expected to increase an economy's output of goods and services and contribute to economic development. Education and training are a form of investment to individuals in which case economic returns on this investment accrue in the form of increased earnings. For companies, the economic returns are realized through gains in productivity and profits. For an economy, the returns are found in the expanded output of goods and services and economic growth.

Development of human capital not only leads to higher worker productivity but also facilitates the absorption of workers into the economy and improves their job mobility (ability to move into more productive jobs and sectors). Reducing skills bottlenecks significantly enhances the efficiency of the labour market. Investment in human capital also enhances business and technological innovation by improving the capacity of workers to apply and adapt existing knowledge and processes as well as make new discoveries.

Africa has huge employment potential and a large section of its areas of investments ventures still virgin. The biggest problem has always been the lack of knowledge, confidence, exposure, skills and the associated fear of business failure. Vocational and entrepreneurial training have, in a number of cases given investors confidence and helped break the wrongly perceived proverbial "glass ceiling" to success.

\section{Objectives of the Paper}

This paper seeks to:

i). Update knowledge about the status of technical - vocational education and training in the region,

ii). Explore issues challenging recent growth in technical - vocational education and training in the region

iii). Point out impact and policy messages to guide skills development in the region.

\section{Current Status of TVET in Africa}

TVET systems in Africa differ from country to country and are delivered at different levels in different types of institutions, including technical and vocational schools (both public and private), polytechnics, enterprises, and apprenticeship training centres. For example, in West Africa traditional apprenticeship offers the largest opportunity for the acquisition of employable skills in the informal sector. In Ghana, the informal sector accounts for more than 90 percent of all skills training in the country.

In all of Sub-Saharan Africa, formal TVET programmes are school-based. In some countries, training models follow those of the colonial power. In general however, students enter the vocational education track at the end of primary school, corresponding to $6-8$ years of education as in countries like Burkina Faso and Kenya, or at the end of lower or junior secondary school, which corresponds to $9-12$ years of what is called basic education in countries like Ghana, Nigeria, Mali and Swaziland. The vocational education track has the unenviable reputation of being a dead end so far as academic progression is concerned and fit for those pupils who are unable to continue to higher education. A case in point is where Nigerians have historically considered Vocational Training and Education (VTE) as an education programme meant for low level, low brilliant and less privileged or second class citizens (Okoro, 1993, and Eze and Okorafor, 2012)

The duration of school-based technical and vocational education is between three and six years, depending on the country and the model. Some countries like Ghana, Senegal, and Swaziland in an attempt to expose young people to pre-employment skills have incorporated basic vocational skills into the lower or junior secondary school curriculum. However, technical and vocational education for employment is unlikely to be effective when delivered concurrently with general education in junior secondary schools. This is because employment-oriented training requires inputs in human (qualified instructors) and material resources that are not available or too expensive to provide in all junior secondary schools or even in a cluster of secondary schools. Such initiatives were tried in the formative years of the 8-4-4 education system in Kenya and to date there is little, if anything to show in form of improvement in technical skills of primary and secondary school graduates. Vocationalisation of the junior secondary school curriculum should therefore be viewed with caution. A good basic education provides a solid foundation for a good technical and vocational education. The only cases in which vocationalisation may be helpful is probably in the use of computers, general agriculture or farming and entrepreneurship. Computer literacy is relevant to all occupations while the teaching of basic agriculture and entrepreneurship are not capital-intensive or too costly.

Regarding the governance of TVET, oversight responsibility is shared in general between the ministries responsible for education or technical education and labour or employment, although some specialized vocational training programmes (in agriculture, health, transport, etc.) fall under the supervision of 
the sector ministries. In spite of the multiplicity of training programmes, the place of TVET in the school system in many countries is marginal both in terms of enrolments and number of institutions (Atchoarena, et al 2002).

\section{Challenges and Drawbacks to TVET Growth}

The socio-economic environment and the contextual framework in which TVET delivery systems currently operate on the continent may not be the best for TVET growth and prosperity. This poses a number of challenges and limitations that need to be given a re-look if TVET has to achieve its targeted objectives.

Poor rate of proportional job creation: The per capita income of most Sub-Saharan African countries (outside South Africa) is less than US\$400. Although the economy in a few countries, including Botswana, Kenya and Ghana, is growing at a respectable rate of about $5 \%$, the annual real growth rate in many countries is less than $2 \%$, limiting the prospects for employment creation. On the other hand, it is estimated that about 500,000 young people add to the labour force each year in Kenya, as many as 700,000 in Tanzania and 250,000 in Zimbabwe. This huge deficit in the employment statistics is not unrelated to the high population growth rate of African countries and the increasing number of school leavers arising out of national and MDG (Millennium Development Goals) initiatives which strived to achieve universal primary education (Johnson, et al 2004).

Wide spread management: Technical and Vocational Skills Development in Africa occurs at different levels of education. Governments and donors need to produce the mix of skills that best corresponds to the requirements of countries (Kingombe, 2008). Except for a few countries (notably, South Africa, Botswana, Mauritius, Tanzania, Malawi, and Namibia), TVET provision in Africa is spread over different ministries and organisations, including NGOs and church-based organisations, with a multiplicity of testing and certification standards which has negative impact on standards, cost saving and quality assurance. In the informal sector, traditional apprenticeship, which is often the only means for the rural poor and the economically disadvantaged to learn a trade is marginalised, unregulated, and lacks government support and intervention.

Zero or negative growth of employment in the Industrial sector: Poor or low growth of the industrial sector has not done any good to the situation. Apart from Botswana, Ivory Coast, Ghana and South Africa, the industrial labour force is less than $10 \%$ in most African countries (World Bank, 2000). In many African countries, with the notable exception of South Africa and Mauritius, about $85 \%$ of the workforce is in the informal, non-wage employment sector. This labour force distribution pattern needs to be kept in mind when developing national TVET policies and strategies.

High illiteracy levels and high dropout rates in schools: Africa still has the distinction of being the continent with the lowest literacy rates to an extent that illiteracy rate in many countries is still high at over $50 \%$. Of significance to TVET is the fact that enrolments at the secondary school level, where TVET is normally provided, is also low with only a few countries having a gross enrolment rate of over $50 \%$. Average completion rates are $80-90 \%$ for primary school; $30-40 \%$ for lower or junior secondary school; and about $20 \%$ for senior secondary school. And only $1-2 \%$ of the college age group actually enter the universities and other tertiary institutions. In Ghana, for example, $49.1 \%$ of the total workforce is illiterate and only $3.9 \%$ have had any vocational or technical training (Ghana Statistical Service, 2000).

Mismatch between college training and market labour demands: This situation has led to a case where there are a huge number of unemployed graduates even though the market needs skills. Critics argue that the lack of inputs from prospective employers into curriculum design and training delivery are partly responsible for the mismatch. Another reason that is often cited for the incidence of high unemployment among graduates is the absence of entrepreneurial training in the school curriculum.

Poor budgetary allocations to TVET: Most African governments give minuscule budgets to TVET hence denying them a chance for quality training. Ethiopia spends only about 0.5 percent of its education and training budget on TVET while Ghana spends only about 1 percent. The figure is 10 percent for Mali and 12.7 percent for Gabon. It must be recognised that TVET is expensive on a per student basis. In 1992, Gabon spent as much as US\$1,820 per TVET student (Johanson and Adams, 2004). Unit costs are necessarily expected to be higher in TVET institutions than in primary and secondary schools because of smaller student-to-teacher ratios, expensive training equipment, and costly training materials that are "wasted" during practical lessons.

Theoretical training versus practical training: In Africa, there is undue emphasis on theory and certification rather than on skills acquisition and proficiency testing. High quality skills training requires appropriate workshop equipment, adequate supply of training materials, and practice by learners.

Low impression and attachment to TVET: For many years, technical and vocational education in Africa has been considered as a career path for the less academically endowed. This perception has been fuelled by the low academic requirements for admission into TVET programmes and the limited prospects for further education and professional development. Worse, the impression is sometimes created by governments that the primary objective of the vocational education track is to keep dropouts or "lockouts" (i.e. students who are unable to move up the educational ladder, not because of poor grades but because of lack of places at the higher 
level) from the basic and secondary school system off the streets, rather than project this type of training as an effective strategy to train skilled workers for the employment market and for sustainable livelihoods.

Lack of effective feedback mechanism: Training institutions do not track the employment destination of their graduates. Consequently, valuable feedback from past trainees on the quality of the training they have received and the opportunity for their experience-based inputs to be factored into the review of curricula and training packages are lost. Current training programs in many countries are supply-driven leading to nontargeted skills development. In other words, the implementation of tracer studies that can improve the market responsiveness of training programmes is currently absent in many countries.

Competition from Developed Economies: Globalization and its effects on African economies especially in terms of trade also limit the significance of TVET. As seen before, globalization has led to stiff competition that is indiscriminative and does not spare even the young economies. Globalization invites not only the international transfer of goods and services, but also the influences of the transfer of production technologies and consumption patterns that decrease the demand for products and services from the TVET sector. African economies are forced to import products from abroad because they are cheaper and of higher quality than those produced inwardly. This has strangled the growth of TVET because there is hardly any market for their products.

\section{Impact and Improvements to Technical - Vocational Education And Training}

In rural areas where technical, vocational and entrepreneurial education has been given attention there has been a remarkable reversal of the rural to urban migration, while at the same time offering skills leading to self employment thus alleviating unemployment. In South African, women who underwent technical education showed marked improvement in businesses ventures and were more settled and confident (Botha et al, 2006). However, in some countries the role of TVET in promoting rural development is over-ambitious. In Kenya, for instance the Youth Polytechnics were established on the idea that they were to contribute to rural development. Studies (Owiro and Migot, 1981: Fergusion and Barker, 1990: Matanga, 1992) show that the role of youth polytechnics tend to depend on the pre-existing levels of rural prospects.

The level of poverty in the rural areas affects the ability of the community members to support TVET institutions and trainees. Matanga, (1992) asserts that in a poor communities there will be difficulties in raising funds, school fees, in creating employment, providing contracts and even in buying goods and services from the trainees. As suggested in an SBP paper (2009), funding business ventures should go hand in hand to TVET training to ensure meaningful and economically sound impact. In addition, in most rural areas, important facilities such as water, electricity, roads are missing; this may limit the scope of training offered to trainees in the rural areas.

The belief that skill acquisition through TVET will lead to creation of jobs especially in the informal sector through self-employment instead of job-seeking is also over-ambitious. This is because self-employment is faced with sharp competition and sluggish economic growth especially in the rural areas, it is also undermined by great competition from urban industrial goods and imported goods. Presence of unfavorable political and economic policies leads people into seeking rather than creating jobs. It must be appreciated that skill acquisition does not create jobs; the prevailing economic policies must be favorable for the skills acquired to be applicable in the creation of jobs.

In some African states, the youth have turned to be a social problem due to their lack of occupation. This situation has been made worse by the over reliance on the Agricultural sector which is either saturated or poorly managed hence not doing much to help. With TVET initiatives this can be reversed once the youth are empowered by the skills and knowledge they acquire. The Ministry of Foreign Affairs-Denmark, in their paper, Realising the Potential of African Youth, state that the African youth lack jobs, resources, knowledge and education and hence are boxed out of the opportunities for growth. The paper reminds Africa that the agriculture sector is hardly expanding despite the huge investment. The paper recommends a demand driven education that targets more productive employment and private sector development

The potential of TVET is also greatly limited by the low government investment towards this sector. Rao, (1996) observed that in most developing countries the ministries responsible for running and directing these centers are either not equipped to pay attention to this aspect or are pre-occupied with other sectors of education leaving the TVET at the mercy of market forces. This fact is highly collaborated by a study on entrepreneurship training that reveals Africa has only 5\% of its students enrolled in tertiary institutions (Mbijjiwe et al 2013) and school systems lack entrepreneurial training. A study for the World Bank by Ziderman (2002) found out that virtually all training systems in Sub-Sahara Africa have to deal with the reality of diminishing government funding for public sector training. Funding towards TVET programs is ad hoc and arbitral, leading to year after year variations and uncertainty, hence a minimal impact in the final analysis. 
Obvious positive impact has been diminished in most African countries by under investment in TVET sector. This is made worse by the emphasis placed on the general academic sector by the governments. For instance, in Kenya, according to the National Development plan on education, training and capacity building, for the period 2002-2008, the budget allocation to TVET under sub sector of education and training was about $0.7 \%$ of the recurrent expenditure. The Germany system of vocational training (commonly referred to as directed and dual system) has frequently been referred to as an example of excellent practice of technical vocational education and training (Beardwell and Holden, 2001). Employers fund two-third of the training and together with trade unions and the local government, they have a considerable influence on the control of the system. Laws and guidelines of vocational training and education regulate the system so that employers are duty bound to provide funding and resources for training. Employers' unions and the state administer the institutions and procedures that operate the system jointly. Firms pay for on-the-job training, youths accept relatively low wages, and the vocational colleges are paid for by public funds (Beardwell and Holden, 2001).

Although it would be expensive to transfer the Germany's dual system as a whole or in component to Africa, it is important to note the influence exerted by organizations on funding for the on the job training and in regulation of skills being offered. In African countries, organizations' influence in the running of TVET is almost zero. TVET is entirely a responsibility of the government and especially the trainees. The growth of TVET sector is also limited by the negative attitude exhibited by people towards vocational training. Many people tend to relate TVET especially the vocational part of it to failures. A study by Mureithi (2008) on the challenges facing youth polytechnics in Rift Valley province, Kenya found out that parents believe that only those who fail to make it to the secondary schools should be admitted to the Youth polytechnics. Well, this notion may arise from the idea upon which TVET was established. The youth polytechnics for instance were established 'to complete the unfinished business of primary school' (Tum, 1996). Continued offering of courses considered 'traditional trades' also causes most people to view vocational training negatively. Kerre (1995) concedes that, generally efforts at providing effective TVET in Africa have not succeeded and vocational training still receives low status.

Arising from the above discussion, three issues need to be addressed to improve skills training for the informal sector: paradigm shift in the training institutes, revamping and scaling up successful programs, and financial subsidies.

Paradigm shift in Vocational Training Institutions (VTIs). It is unclear whether existing public sector training centres can make the sweeping changes needed to serve the demands of the informal sector. Most would have to make major changes in identifying market trends, translating them into training programs, and finding appropriate delivery modalities to reach new target groups. It may be preferable to use master crafts persons for the training. Moreover, reorientation of existing training centres requires major investments to upgrade facilities and equipment; to attract, develop, and retain new staff; and to develop new curricula and materials. Quality improvements require resources in excess of current public subsidies. Increased training fees are not likely to prove feasible in view of the poor benefits of past training and constraints on family incomes.

Revamping and wide scale growth of structures: Most of the successful examples of training for the informal sector, and for literacy and livelihood skills, consist of small projects. Sponsors provided intensive inputs to develop programs responsive to local demand. These precedents, therefore, provide no recipe for quick expansion to mass provision. Rather, working in partnerships with communities and NGOs and ensuring adaptation to local demand requires slower growth and long-term commitment. One unanswered question concerns the extent to which traditional apprenticeship can help transfer basic technical skills to the burgeoning number of people entering the informal sector. Expansion of coverage is inherently limited by the number of master crafts persons willing to provide training. On the other hand, the Kenya Jua Kali project, done on a relatively large scale, is a good example of scaling up.

Public Financial Subsidies: Full cost recovery has proven elusive in informal sector training. There is a legitimate role for targeted government subsidies for pre-entry courses that facilitate access by disadvantaged groups to self-employment. Cost recovery can be only minimal, or perhaps deferred. The case is less clear for in service training because it carries few of the external benefits, and the informal sector operators benefit immediately. This suggests a policy of using subsidies for pre-service courses but attempting to recover as much of the in-service training costs as possible, with increased cost-sharing gradually replacing subsidies (Ziderman, 2003).

\section{Conclusion}

This paper concludes that in spite of the limitations put afore, the importance of TVET to the development and industrialization of African economies cannot be overemphasized. Africa needs to be more inventive and innovative in a way she can develop solutions to her problems internally. The indiscriminate adoption of foreign technologies and theoretical concepts of the developed countries is a misnomer, this is because we must appreciate that the developed countries industrialized and developed within different contexts 
and circumstances that differ from the context and circumstances facing African countries today. TVET thus remains significant because it provides an opportunity to develop practical solutions to African problems, based on a thorough analysis of the prevailing conditions.

A well established TVET system should lead to the development of technologies that are tailored towards meeting the needs of the community. However, it must be accentuated that acquisition of skills is not sufficient to eliminate all the problems facing African economies. It is a prerequisite, but a lot more needs to be executed. Political instability, poor governance, poor economic policies and unequal distribution of income among other ills must be abolished if the significance of TVET is to be felt.

It is worth noting that Africa needs to redouble its TVET initiatives because economic development and poverty reduction requires investing in the productivity and skills of economically and socially vulnerable groups. This is one of the main messages of Can Africa Claim the 21st Century? (World Bank 2000). Investment in people is important for two reasons: Africa's future economic growth depends less on its natural resources, which are being depleted and are subject to long-run price declines, and more on its labour skills and its ability to accelerate a demographic transition.

Development is not feasible without a strong technological system. Exploiting the potential of information and communications technology (ICT) requires a strong skills base (as well as infrastructure and appropriate regulatory frameworks). Adoption of ICT is associated with the employment of more skilled workers. A labour force with a solid basic skills foundation is essential for countries to exploit the opportunities opened by technological change (Betcherman 2001).

Globalisation should be handled cautiously. Globalization has both positive and negative impacts on economies. For weaker economies, globalization may cause them to go worse from effects of intense competition. Richardson argues that in a global economy, the hitherto accepted 'infant industry economy' will no longer be sustainable. Globalization will lead to mega-competition and may 'hollow out' industries and have major impacts on labor markets (Richardson, 2001).

\section{Recommendations}

In the foregoing discussion, it is evident that the significance of TVET is not being felt in Africa because of the limitations facing this sector. Thus, this paper suggests that;

- There is need for increased funding towards TVET in Africa. This should be directed towards research and development, acquisition of appropriate and up-to-date equipment and tools and general maintenance and management of TVET institution.

- More attention or equal attention should be offered to the TVET sector as that offered to the general academic education since a well working TVET will be the next step to school graduates.

- There is a need to emphasis on rural development in order to reduce income differences between the urban and rural areas. Thus, those with technical and vocational skills will not have the urge to transfer their skills to already overpopulated urban areas where their skills become unutilized. In addition, more TVET institutions should be established in the rural areas and they should emphasis at providing technical and vocational skills to meet the needs of the community.

- There is also need to look into the economic policies upheld by our countries. Ways and means in which capital can easily be obtained by those with entrepreneurship skills but are unable to start income generating activities due to lack of capital should be established. governments should encourage the development of micro finances and also through their national commercial banks offer friendly loans to even the poor and young entrepreneurs willing but unable to establish money making activities.

- Although the effects of globalization are inevitable, governments need to develop policies that protect their economies against harmful importation of products and services that discriminate against those goods produced internally. This can be achieved by looking inwards and encouraging domestic production to substitute for imports.

- To ensure that TVET is more market driven, it is necessary for the governments to involve organizations in the formulation of the curricula and in the certification of skills offered. In addition the governments should encourage organizations to participate in providing on the job training by creating incentives for companies by reimbursing training costs, by subsidizing apprenticeship wages and for those companies who earn huge profits, by allowing for tax concessions.

\section{Acknowledgement}

In the production of this paper, we thank the almighty God for the grace and strength to shoulder on. We extend our gratitude to our families, colleagues at work and friends for the invaluable support. May God bless you all. 


\section{References}

[1] Afyenyandu, D, King, K, Mcgrath, S, Oketch, H, Rogerson, C and Visser, K (1999). Learning to Compete;

Education, Training and Enterprise in Ghana, Kenya and South Africa; Education Research Paper No 42. Center for African Studies; University of Edinburgh

[2] Armstrong, M. (2003) A Handbook of Human Resource Management Practice. London: Kogan Pages

[3] Atchoarena, D and Andre Delluc (2002): "Revisiting technical and vocational education in Sub-Saharan Africa". IIEP-UNESCO, Paris.

[4] Beardwell, I.and Holden (2001) Human Resource Management: A Contemporary Approach.Great Britain: Pearson Education Limited

[5] Botha, M. G.H. Nieman and J.J. van Vuuren (2006). Evaluating the women entrepreneurship training program: A South African Study. International Indigenous Journal of Entrepreneurship, Advancement, Strategy and Education, ISSN 1177-0317, University of Pretoria, South Africa. Accessed through www.indigenousjournal.com on $5^{\text {th }}$ April 2013

[6] Eze, T. I. \& Okorafor, O A. (2012). Trends in technical, vocational education and training for improving the Nigerian workforce. Ebonyi Vocational and Technology Education Journal. 1(1), 107-11

[7] Ghana Statistical Service (2000): "2000 Population and Housing Census". Accra, Ghana.

[8] Government of Kenya, (2002) National development plan 2002-2008: effective management for sustainable economic growth and poverty reduction: Ministry of planning and development: Nairobi

[9] Government of Kenya, (2003) Rapid appraisal on the status of technical and vocational education and training (TIVET) in Kenya. Nairobi: Ministry of Education, Science and Technology

[10] Government of Kenya, (2005) The executive summary of the paper on 'The role of education and training in transforming Kenya into a newly industrialized country by the year 2020. Nairobi: Ministry of Education, Science and Technology

[11] Jhingan (1985) The economics of development and planning. New Delhi: Vikas publishing house limited

[12] Johanson, R.K and A.V. Adams (2004): "Skills Development in Sub-Saharan Africa". The World Bank. Washington DC.

[13] Kerre, B. W. (1995). Technical and Vocational Education in Africa: A synthesis of case studies. Dakar, Senegal: UNEVOC/UNESCO International Project on Technical and Vocational Education), Regional Office.

[14] Kingombe C. (2008) Evaluating the Effects of Vocational Training in Africa, Policy Insights, OECD No.61,April 2008 accessed through http://www.oecd.org/dev/emea/40583752.pdf

[15] Manpower Group (2012). Youth Employment Challenge and Solutions.pg 5 retrieved on $30^{\text {th }}$ April 2013 from http://www3.weforum.org/docs/Manpower_YouthEmploymentChallengeSolutions_2012.pdf

[16] Matanga, F.K. (1992) The role of youth polytechnics in rural development. The case of Bungoma District

[17] Mbijjiwe J. and C. Kathure (2013) Entrepreneurship Training and Early Retirement: A TwinMuzzle Solution to Un-Employment in Africa, IOSR Journal of Business Management, Vol 14: issue No.4, November 2013.

[18] Ministry of Foreign Affairs-Denmark (2009). Realising the potential of African Youth.

Report of the African Commission, $9^{\text {th }}$ June 2009 accessed through www.netpublikationer.dk/um/9336/index.htm on $6^{\text {th }}$ April 2013

[19] Mureithi, G.W (2008) challenges facing vocational training centers in human resource development: the case of Youth Polytechnics in Rift Valley Province, Kenya

[20] Okolocha, C. C (2012) Vocational Technical Education in Nigeria: Challenges and the Way Forward, Business Management Dynamics, Vol.2, No.6, Dec 2012, pp.01-08 accessed through http://bmdynamics.com/issue pdf/bmd110281,\%2001-08.pdf

[21] Okoro, O. M. (1993). Principles and Methods in Vocational and Technical Education. Nsukka University Trust Publication.

[22] Rao, T. (1996) Human Resource Development, Experiences, Interventions and Strategies. New Delhi: Sage Publications

[23] Richardson, P. (2001) Globalization, Socio-economic Development and Employability: The role of education and training. United Kingdom: Manchester Business School

[24] Rothwell, W. and Kolb, J. (1999) Major workforce and workplace trends influencing the training and development field; International journal of training and development, 344-353

[25] SBP Alert (2009).Boosting Youth Employment Through Entrepreneurship-A response to the National Youth Development Agency, An SBP occasional paper, June 2009 , Copyright: (C) SBP 2009, pg 6, accessed through http://www.sbp.org.za/uploads/media/SBP_ALERT_youth_employment_june_09.pdf

[26] World Bank (2000): "African Development Indicators 2000". The World Bank. Washington DC.

[27] Ziderman, A. (2002) Financing vocational training to meet policy objectives: Sub-Sahara Africa.The World Bank 